DE DE GRUYTER OPEN
Research Article

(C) 2017 Boy Nurdin.

This is an open access article licensed under the Creative Commons Attribution-NonCommercial-NoDerivs License (http://creativecommons.org/licenses/by-nc-nd/3.0/).

\title{
The Role of Philosophy in Enhancing the Quality of Human Resource in Indonesia
}

\author{
Dr. Boy Nurdin \\ Universitas Bhayangkara Jakarta Raya, Indonesia
}

Doi: 10.1515/mjss-2017-0035

\begin{abstract}
The main purpose of philosophy is to describe how people may live and grow in better ways (Husserl, E.) ${ }^{1}$. The facts have shown that, once philosophy is involved, the character of people is thereby developed, leading them to have a better life. It is not only important for people to know about philosophy, but it must go beyond that point and be deeply understood, internalised, and practiced frequently. This paper will discuss the role of philosophy in order to show how the quality of human resource may be enhanced, in particular in Indonesia, in short-and long-term plans. The role of philosophy will determine whether the ultimate goal of understanding philosophy - which is to stimulate people to have critical, logical, comprehensive, and in-depth ways of thinking in their own field of expertise, which enables them to solve problems raised and faced in life - is going to be achieved in improving the quality of human resource in Indonesia. In addition to that, the educational sector should also be taking part in reaching this goal. People as individuals, who possess a good character and are always thinking philosophically and practicing the concept of philosophy in their daily lives, will achieve an exceptional life that is not only responsible and beneficial to themselves but also to their environment, surroundings, and communities.
\end{abstract}

Keywords: Philosophy, Character, Critical, Logical Thinking, Human Resource

\section{Introduction}

A philosophical approach to human life can be used in combination with other approaches, such as Science, Art, and Religion. Philosophy as a science has been defined as seeking and understanding something and its meaning and values. As far as the mind is concerned, philosophy is an attempt to search for the origin, nature, and purpose of the universe in which man lives. The goal of philosophy is to attain real and true understanding and wisdom.

Philosophers seek to unite science with their understanding of morals, aesthetics, and religion. Philosophers seek an integrated outlook on life, try to find the meaning of life, and conceptualize the universe and the place of man living within it. The meaning of philosophy can be defined as an attitude, a method, a problem, a theory or system of thought, or a logical analysis, or it can be interpreted as an attempt to gain a holistic view. Philosophical thinking is required for human resource individuals who aim to achieve a good life and be of benefit to their own lives, surroundings, and communities.

In the case of human resource in Indonesia nowadays, it is found that people in all levels do not draw on philosophical thinking. They do not think radically/radix (they do not understand things

\footnotetext{
${ }^{1}$ Famous as one of the XIX Century philosophers is EDMUND HUSSERL (1859-1938). Born in Prostejov Czechoslovakia state in 1859. He came from an orthodox Jewish family. The period of 1886-1887 was an important year for Husserl. He moved to Halle, and studied psychology, wrote The Philosophy of Arithmetic.
} 
for their real meaning, essence, and substance). They even think incoherently, inconsistently, and unsystematically (they tend to think illogically and not in line with the rules). They also think incomprehensively and tend to be close-minded (limited to extended knowledge from social, historical, cultural, and religious contexts).

The country of Indonesia is struggling to achieve significant change in order to reach its vision of becoming an important nation. Through a dynamic process, Indonesia has put its efforts towards change, a so-called "Reformation", which relates to the new values, norms, procedures, etc. (Bagir Manan, 2001: 4). However, it has been 15 years since former President Suharto's step-down in 1998, and change for a better nation as expected in the Reformation goals seems to be hardly reached in most parts of life. Reform in the human resource area is urgently required in Indonesia. Good-quality human resource in Indonesia is expected to be able to tackle the issues raised in the country. It has been established that many people in Indonesia work inappropriately in accordance with their field of expertise. They have a mostly insufficient capacity to deal with their task. Therefore, they have no ability to be good decision makers who are capable of making hard and correct decisions for the country which lead to benefits for many people and the common good. In fact, the increasing standard of living and level of education they possess does not guarantee they are doing good for the people. They even become perpetrators who are damaging things that are already good for the sake of their own benefit - individual and groups. This is true according to the argument expressed by John Locke (1632-1704) saying that "The mankind is basically good in nature". He also spoke of "a state of peace, good will, mutual assistance and preservation". ${ }^{2}$ John Locke argued that when money was created the atmosphere of life was changed. Man, by money, has something beyond the intended limits. ${ }^{3}$ The root of the problem was actually found to be that low-quality human resource has the least philosophical thinking. It then becomes important to consider that Philosophy Science should be taught in higher education and defined as a National Compulsory Subject in all levels of higher education. Philosophy would then no longer only be studied by students in order to meet a passing grade, but would be in line with the deeper meaning of the main purpose of learning philosophy.

This paper will discuss the role of philosophy in enhancing the quality of human resource in Indonesia and the strategy that can be proposed in order to enhance the quality of human resource in the short- and long-term phases. In addition, this paper will also conclude whether any effort can be recommended from the perspective of the educational sector in participating in improving and enhancing the quality of human resource in Indonesia.

\section{Philosophy: Theories and Reviews}

The name philosophy was derived from the Greek language. Furthermore, the concept of philosophy has also been shown to be a Greek invention. A small country like Greece is amazing as it displays various miracles. This is why then the emergence of philosophy is usually called "miracle" by the Greek people. This indeed shows the glory and superiority of the Greeks. Philosophical thinking shows the characteristics, as follows: ${ }^{4}$

- Radical (radix in Greek means "root"): Thinking up to the root, seeking the essence or substance of something.

- Universal (general): Thinking in regards to various matters, including the process of general human nature (common experience of mankind).

- Conceptual: Thinking in general perspective and abstraction from individual experiences.

- Coherent and consistent: Thinking in accordance with the rules of logical thinking and coherency.

- Systematic and comprehensive in looking at various elements: Thinking connectively and accordingly, with good planning in order to achieve certain goals.

\footnotetext{
${ }^{2}$ A state of peace (wilayah yang damai); good will (itikad baik); mutual assistance and preservation (saling membantu dan memelihara/menjaga).

${ }^{3}$ Abd. Rohim Ghazali. "Manusia, Kekerasan dan Fungsi Agama". Opinion of Kompas, November 4, 2002. Page 6

${ }^{4}$ Ibid., page 2
} 
- Thinking comprehensively and covering the whole matter.

- Feeling free, to a great extent as in free of social, historical, cultural, or religious prejudices.

- Responsible, especially to the conscience itself, such as moral and ethical responsibilities.

Philosophy is the pioneer of science. The specialization of science has grown afterward and is increasingly detached from philosophy as its master. The philosophy of science has been progressing slowly compared with later-emerging science, like natural science. Philosophy has proven to be even more like art than science. Philosophy has also never been a universal science. The role and function of philosophy cannot be replaced by any science because science itself is outside of philosophy and never touches the basis of human problems. Philosophy is a forum or place where open discussions can be had to seek wisdom in the midst of science. Philosophy seeks fundamental human problems that must be faced openly, profoundly, systematically, critically, and not a priori or prejudiced, not dogmatic and ideological, but rationally and argumentatively.

The main purpose of philosophy, according to Edmund Husserl, is to give directions on how human beings should live and grow in the best way. Furthermore, Husserl even said that the current philosophers today prefer to criticize something without seeking and exploring things deeply in order to understand them. It is difficult to restore philosophy to its original purpose because it relates to the perception of an individual. Philosophy, so far, is taught at school as a boring lesson of memorization. The way for people to understand philosophy has not been delivered by appropriately responding to questions about how to live in ways that bring about a good life to an individual, a family, environment, or nation insofar as the limits of human life as a whole. Philosophy as a knowledge is only delivered in reference to the journey of philosophy as a master of all sciences. Other than that, philosophical knowledge also only describes the history of philosophy, including that introducing the philosophers and their thoughts as well as their different qualities in each century. Whereas, in fact, philosophical knowledge should be delivered in more creative and innovative ways. Hence, it will encourage a person to think critically and comprehensively based on his or her educational background. It is insufficient for people to just only know and understand philosophy as occurs nowadays. It is expected to go beyond that to the stage of internalising philosophy as a living process and practicing it. Many countries, in particular Indonesia, have problems. It was found that it was caused basically by people of all levels in the country who mostly do not reflect philosophical thinking. They do not think in radical or "radix" and are not looking at things for their essence or substance, are incoherent and inconsistent (their thinking is not in line with the rules of logic and coherency). They do not think in systematic ways, and are incomprehensive and ignorant of social, historical, cultural, or religious prejudices.

The root of all problems currently found in the case of Indonesia is the quality of its human resources. The good quality of human beings is defined as when he or she has ways of philosophical thinking which can be developed day by day. Philosophical knowledge is required to be learned, understood, internalised, and further, properly practiced by people. Once it is done, it is very likely that the country of Indonesia will have a high quality of human resources for its future generations.

One expert in the Philosophy of Law, Soerjanto Poespowardojo (2013), said that the existence of the Philosophy of Science is necessary to provide an understanding on how to live and grow as a good human being. In addition to that, other important science and knowledge is needed and classified into the trilogy, which contains the philosophy of science, critical theory, and scientific research methodology. These three components of sciences are required to address various social ills and issues that occur in society, such as frequent ethnic conflicts, crime, and violence. Social phenomena, as well as brawls between students, or community groups, and the increasing number of corruption cases, have become a multidimensional crisis of many countries around the world, including Indonesia. The cultural crisis is part of this multidimensional crisis. The trilogy contains a comprehensive knowledge base and nowadays an intellectual is therefore needed in order to improve philosophy knowledge. These three components are expected to make people become critical and ready to change their mindset, behaviour, and work ethic. When the mindset and work ethic have been changed, there will be significant changes towards the future of the nation. ${ }^{5}$

\footnotetext{
${ }^{5}$ http://www.sesawi.net/2012/10/09/filsafat-harus-jadi-mata-kuliah-wajib-pascasarjana/ downloaded October 10, 2013.
} 
Having discussed the history and theories of philosophy, it is proposed that we have to find out how to restore philosophy to its main purpose in responding to the needs of understanding how people as human beings (human resource) can live and grow in the best ways, and how philosophy's role should be optimized for an individual in order to enhance the quality of human resource in the case of Indonesia for the short- and long-term phases. The components of sciences are needed to be found and explored to address various social ills in Indonesia. The point of view of the educational sector is therefore to be investigated further to achieve the goal of enhancing the quality of human resource for Indonesia.

\subsection{Philosophy: Its Role in Human Life-Enhancing the Quality of Human Resource}

According to Socrates, ${ }^{6}$ virtue is knowledge (theoria). The wise man is the one who knows something, while the sinner is the foolish one. People with sufficient and appropriate knowledge will lead themselves to the right action; evil acts are a result and an unfavorable insight. Therefore, the human being requires to be taught and given an understanding of the greatness and truth of life. By knowing the truth, a man will do wisely and he will then be able to act better and make less destruction in society. Thorough training and discipline is therefore required in order to achieve a goal—being a "Wise Man" (Nurdin, 2012).

Socrates's disciple or student, namely Plato ${ }^{7}$ is widely regarded with the highest honour in the glorious period of Greek philosophy. Plato's philosophy is basically the development themes of Socrates' thought.

There are two fundamental concepts underlying the assessment of human resources in Plato's philosophy (Schmandt, 2002), as follows:

\section{Virtue is Knowledge/Theoria}

Everything that is "good" can only be found with the medium of "Science and Knowledge." In the doctrine it is raised that virtue is knowledge. According to Plato, there are three concepts, namely:

- Truth should be objective and consistent, so that we can attain knowledge about it;

- Due to virtue being equated with knowledge, the person who owns and knows the knowledge should be given a decisive role in public affairs.

- In the broader context, the country/states should take an active role in educating their people, especially those who are trusted with the guidance and direction of public life. Society will be increasingly wise and well-functioned by training to gain a broad range of skills.

The meaning of the word "virtue" is generally used to show both moral and intellectual goodness. Plato divides virtue into four principal elements, namely: wise, firm, simple, and fair. The wise man is the one who knows something and possesses sufficient knowledge to lead him to take the right action. Hence, human beings need to be taught and get understanding of the greatness and the truth of life. Having known the truth, man will act wisely and be less destructive in society.

2. Inequality between Humans: Humans have Different Talents, Intelligence and Abilities

Plato says that everyone has a different capacity to acquire true knowledge. Plato argues that humans are essentially unequal in terms of intelligence and potential. Even if all human beings have similar inheritance capacity, only a few can think logically and manage their passion and desire; and only when reason dominates in absolute terms, then the soul

\footnotetext{
${ }^{6}$ The Greek Golden Age was initiated by a thinker named SOCRATES (470-399 BC). Born in Athens in 470 BC. He was the first major philosopher born in Athens. This Socratic period is referred to as the Peak of the Classical Period (Greek Golden Age) where it is said that the mind is the most important norm.

${ }^{7}$ Famous as one of the Greek Golden Age Philosophers named PLATO (427-347 BC). He is Socrates disciples and teachers of Aristotle. Born in 427 BC, in the middle of an aristocratic family in Athens in a time of great change. The basis of Plato's is a good mind (Budi yang Baik in Indonesian language). Mind here means Knowing. The knowledgeable man is automatically virtuous person. According to Plato, Philosophy is the science with interests to achieve the original truth.
} 
can reach reality. Plato does not believe the concept of idealistic equality among human beings. He believes and values on people's talent and ability. Plato also believes that nature makes human abilities different one to another, either because of physical or intellectual pursuits or for attaining virtue.

In line with the meaning of philosophy, in which things are good and wise, Edmund Husserl ${ }^{8}$ also said that the main purpose of philosophy is to respond to human curiosity on how to live and grow in the best way. Looking at the prevalent phenomena in Indonesia today and the developing countries in general, there is a point, as Plato says in his book, Republic VI, 499, that "Neither city, country nor individual will ever reach perfection until a group Small Philosophers ..........., with the destiny of God is forced, whether they will or not, to care for the country.....and so" (Schmandt, 2002). Nowadays, where every individual can study philosophy, it is no longer the philosopher who must play an important role. People in all areas of expertise, however, must think like a philosopher. The issue found in a country like Indonesia has shown that only a small number of people can think like a philosopher. This pyramid chart shows deficiencies that might "destruct" human resources in developing countries, particularly for a country like Indonesia.

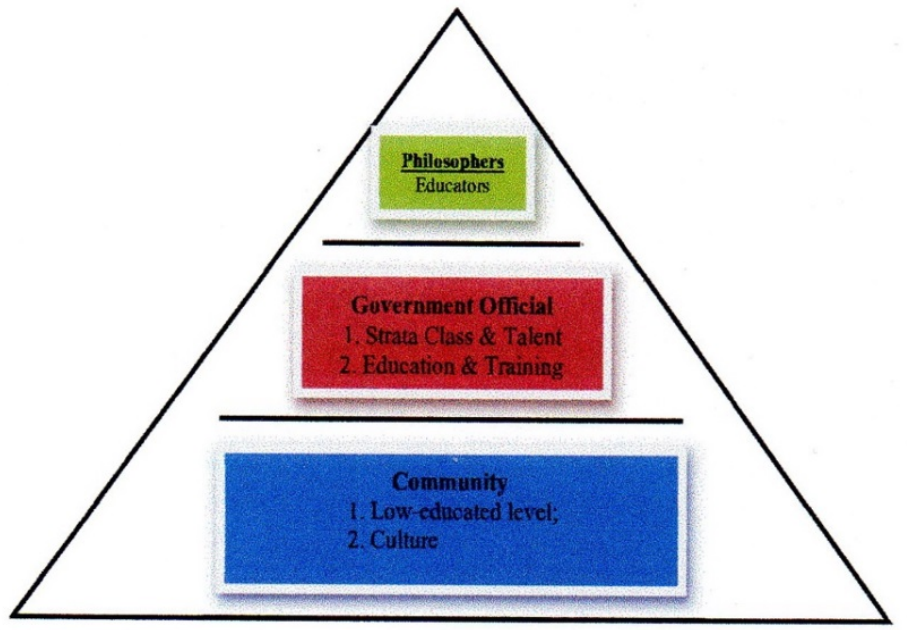

Figure 1. Comparison of Classification for Human Resource in Indonesia: Community with Lack of Philosophical Thinking (in Majority) VS Philosophers (in Minority)

Figure 1 (one) above shows that philosophers, or people who think philosophically, are insufficient, particularly those who are Public/Government Officials who also do not pay attention to the class structure and talents, as mentioned by Plato. Even worse, developing countries, specifically in the case of Indonesia, are dominated by people whose low level of education leads them to sit in a low level of prosperity. Short-term human capital enhancement should be concerned if we consider deeply Plato's philosophy which suggests that it is foolish and meaningless to place an inferior, less capable, and untrained individual in a position of public trust (Schmandt, 2002). Plato does not believe the concept of idealistic equality among human beings. Plato, who values talent and ability, believes that nature makes human capacities different one to another, either because of their physical or intellectual pursuits, for attaining virtue. The decreasing qualities of society in a nation is easily understood because people who work for their country are not chosen in accordance with their talent and ability. They have inadequate education and training in their field of interest's area and capabilities. In other words, there has been a mistake placing someone if they do not fit with

\footnotetext{
${ }^{8}$ Famous as one of the XIX Century Philosophers is EDMUND HUSSERL (1859-1938). Born in Prostejov Czechoslovakia state in 1859. He came from an orthodox Jewish family. The period of 1886-1887 was an important year for Husserl. He moved to Halle, and studied psychology, wrote The Philosophy of Arithmetic.
} 
the ability and required skill.

In regard to the country of Indonesia with its dominant Muslim population, it is therefore important to investigate the nature of philosophy from the religion's points of view. In this case, the Science of Philosophy can also be viewed from the perspective of Islamic philosophy. Islamic philosophy ${ }^{9}$ means thinking free and broadly, radical and meaningful. It has also the nature, style, and character that saves and gives peace of mind. It has been thought that it is all done in mind as one of the human body's organs. The human body itself is part of the self-egoism or "nafs", which can take place a process of transcendence. Thus, this self-egoism or "nafs" is essentially transcendent, which is defined as a process of unity and the unification of the various elements. It finally shapes man's self-actualization.

Having explored what has been done by the Prophet Muhammad (Islamic Prophet), essentially an incarnation of the task of a true philosopher. A true philosopher is not only one who thinks about something great, however, he further involves himself to change a society in relation to how he has developed his philosophical thinking. His extraordinary intelligence enabled him to understand and carry out dual tasks as philosopher and Islamic prophet.

In the concept of Islamic philosophy, "Science or Knowledge" can be obtained through two paths, namely, "Kasbi or Khushuli" and "Ladunni or Hudhuri" (Asy'arie, 2001: 74). "Kasbi or Khushuli" is a systematic and methodical way of thinking that is done consistently and gradually through a process of observation, research, experiment, and discovery. This science is commonly obtained by humans through a formal and gradual process of education.

While the path of "Ladunni or Hudhuri" ${ }^{10}$ is obtained by not going through the process of science, however, it is done by the process of enlightenment with the presence of divine light in qalb (clear-depth heart). The presence of divine light will illuminate the truth, read clearly and absorbed in intellectual consciousness, since the person gain his knowledge from God directly, therefore God is acting as his teacher (Asy'arie, 2001). The science of Ladunni or Hudhuri can be accomplished by cleansing qalb (clear-depth heart) and letting go of egoism and self-confidence to zero, hence likened to standing facing God, like a disciple dealing with his/her teacher. God will come to open the truth and tell us when we are to go out further with the truth itself. ${ }^{11}$ Under such circumstances, a man with a high commitment to the truth being absorbed involves himself in the process of making truth in the life of society. Therefore, those who have attained the science of "Ladunni or Hudhuri" will be characterized by their high commitment and more humanized behavior. $\mathrm{He}$ or she also has a high commitment to defend the truth and adopt it in his/her life in society.

In fact, lessons learnt from the experience, indoctrinating people using a religious approach, seems to be able to succeed for many cases occurring in Indonesia. In order to mold anything we want to include-to enhance the quality of human resource for the Indonesian people-this religious approach is good and is possible of being proposed. However, the points of doctrines should be ensured to use the true religious approaches which are based on the Islamic philosophical concept, "Kasbi or Khushuli" and "Ladunni or Hudhuri". The example shown -how religious approaches will be successfully used to indoctrinate the people of Indonesia (but in

\footnotetext{
${ }^{9}$ As contained in history as well as the concepts given by Muslim Philosophers reveal an "Islamic" style and core. In the sense that the basic conception of philosophy is built on the pillars of the autensity of Islamic views and values not merely as attributes or accidents, it is the essence itself: Islamic philosophy has always been an attempt to explain the way God conveys the Truth or the Essence, with intellectual and rational language. For al-Kindi, philosophy is the knowledge of nature within the limits of human possibility. Hence the aim of his theoretical philosophy is to attain the truth, and with his practical knowledge behaving in accordance with the truth itself. Ibn Sina defines philosophy as the knowledge of existence (qua existence).

${ }^{10}$ The concept of al-'ilm al-hudhuri was first revealed by Syihabuddin Suhrawandi. For Suhrawandi, one can not investigate the knowledge of others who are outside of his own reality before entering and deepening the knowledge of himself called al-hudhuri science. The main feature of this science is proposed by Shirazi (Mullasadra), that self-objectivity is what the real knowing subject and who actually exist in themselves are one and similar.

${ }^{11}$ There are six steps of religious experience that occur in various religious traditions in the world, as follows: 1)Experience yourself to the Holy; 2)The mystical experience of the unity, between God and the individual; 3)Transformative reorientation experience, for example: from separation to unity/reunion; 4)Courage to bear the pain; 5)Experience moral obligations; And 6)Experience the regularity and creativity of nature.
} 
negative ways) -is the extensive use of the power of terrorism in the name of "Islamic thought". That religious approach (regardless terrorism has delivered its wrong doctrines), has made this growing terrorism. For the purpose of this discussion, the true religious approach which is based on the Islamic philosophical concept, "Kasbi or Khushuli" and "Ladunni or Hudhuri", again will hopefully help to enhance the quality of human resource for Indonesia.

Having discussed the thought of well-known philosophers and the Islamic concept of philosophy, it is ultimately expected that a person must be placed according to his/her abilities and areas of expertise. In other words, the following concept of "The Right Man in the Right Place" is supposed to be implemented, particularly for the case of human resource management for the country of Indonesia.

In order to enhance the quality of human resource in Indonesia, it is thus summarized that "A Conceptual Thinking of Enhancement on the Quality of Human Resource by the Philosophical Approach: The Case for Indonesia", which is divided into Short-Term and Long-Term Efforts can be offered, as seen in the Figure 2 (two) below.

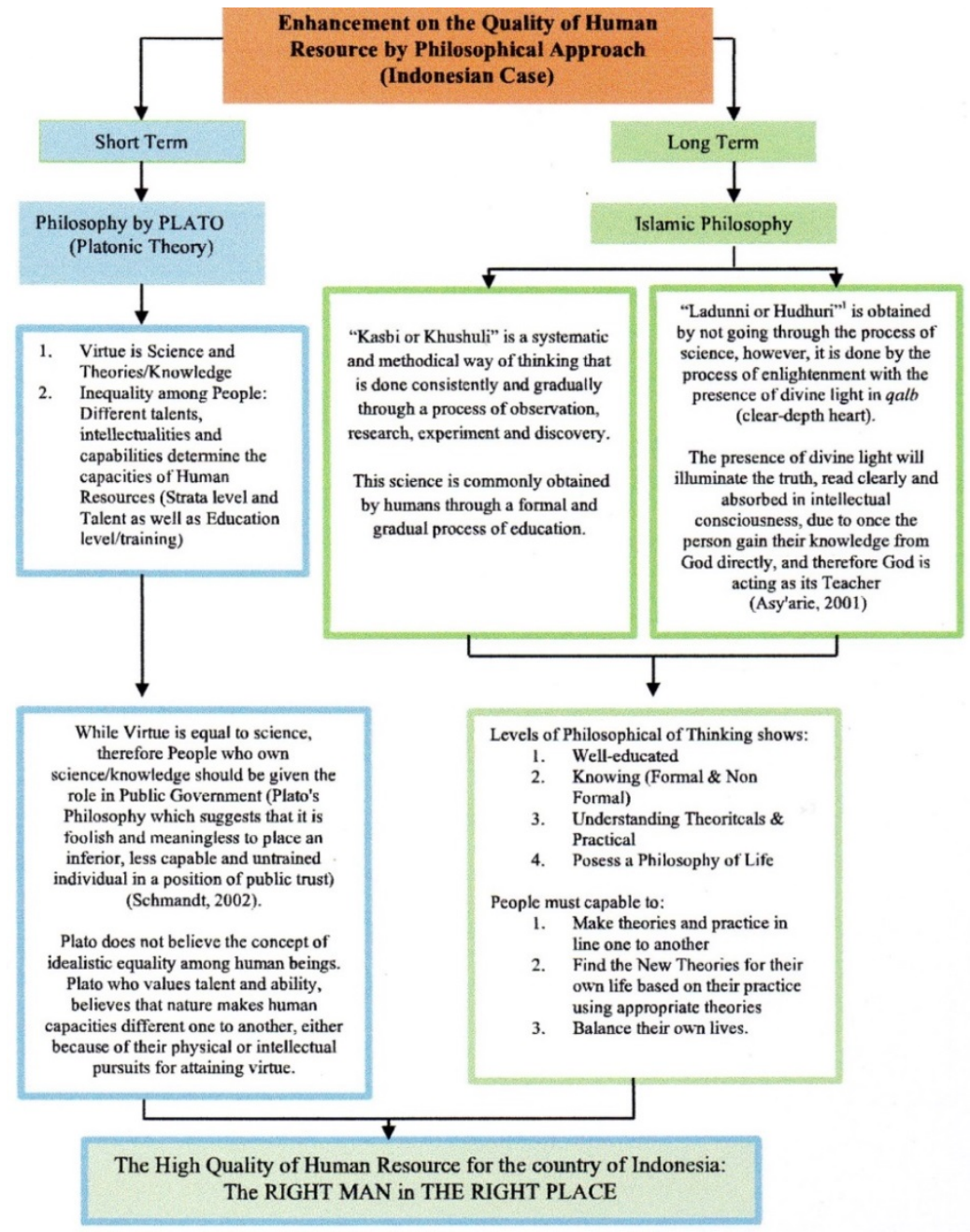

Figure 2. "Conceptual Thinking on Enhancement of the Quality of Human Resource by the Philosophical Approach" (The Case for Indonesia) 


\subsection{Philosophy: Back to its Origins and the Role of the Educational Sector to Build Philosophical Thinking of the People of Indonesia in Order to Enhance the Quality of Human Resource in Indonesia}

As stated earlier, the main purpose of philosophy according to Edmund Husserl is in respond to people who are asking how to live and grow in the best way. However, philosophy in reality has deviated from its ultimate goal. Husserl says that philosophers nowadays love to criticize things, without taking in-depth study and to further understand the matters. To restore philosophy to its original purpose is not an easy way. This is due to the perception of a person toward philosophy that it is only knowledge which only needs memorizing, and further, people will get bored with this philosophical science. Even worse, the meaning and purpose of learning philosophy is not conveyed in proper ways.

Rene Descartes ${ }^{12}$ - father of modern philosophy has his own words "Cogito ergo sum" or "I think, therefore I am". It means that when a man thinks, his existence will be acknowledged. The principle of continuous, critical, and constructive ways of thinking are always used as well as questioning everything that goes against reason and conscience. Auguste Comte ${ }^{13}$ argues that, ideally, man is a theologian in childhood, becoming a metaphysician in his adolescence, and eventually becoming a philosopher in adulthood, who is always finding the answer on how to live well, useful, and beneficial to his own life, environment, and other communities. With critical thinking, it is expected that the next nation's generation will always be looking at and questioning everything from the point of goodness, wisdom, propriety, ethics, and morals, hence, every generation will experience improvement in its own quality as human beings.

In addition to that, the educational sector must take its role to mold the philosophical thinking of individuals, resulting in a high-quality of human resource in Indonesia. The Science of Philosophy should be modified to the way of traditional teaching methods that have been conducted so far at school in higher education. One methodology to be recommended is to put emphasis on how educators should be interactive with students. Educators should have good understanding of the theories of philosophy and its values as well as being ready to become role models for the students. Philosophical Science should also be taught by using of questions and answers in the class, and conducting more discussions or seminars. Questions and answers sessions will be useful for sharpening the students' critical and logical comprehensiveness of the cases. The discussion class will help students to build their conceptual, systematic, and argumentative statements.

\section{Conclusion}

The main problem of most developing countries in the world-one particularly for the country of Indonesia-is the difficulties in achieving the country's development because only a few human resources possess philosophical ways of thinking. The philosophy approach is required and expected to be able to produce qualified human resources, who are professional and obtain a good character. For the case of enhancing the quality of human resource for the country of Indonesia, this can be done through implementing a philosophical approach taught by the Plato philosopher through his Platonic theory and the Prophet Muhammad (Islamic prophet) through his Islamic philosophy called "Kasbi or Khushuli" and "Ludunni or Hudhuri". An approach from the religious context of Islamic philosophy for the country of Indonesia is thought the most appropriate one, with

\footnotetext{
${ }^{12}$ Rene Descartes (1596-1650) was born in La Haye, France in 1596. In his youth Rene Descartes attended a school led by the Jesuit priests in the village of La Fleche. At the age of 20 he obtained a law degree from the University of Poitiers but never practiced his science at all. Descartes was given the title of "Father of Modern Philosophy", known for his book "Dis Cours de la methode" (meaning description of method) in 1637 describing his intellectual development. In this book he was dissatisfied with the philosophy and science that became the subject of his education.

${ }^{13}$ Auguste Comte (1798-1857) is a sociologist. He had Philosophical concept of "Sociology Positivism". He became the God Father of Sociologist. He is the one who explored the sociology in sysmatic ways of thinking and take this sociology independently from Philosophy Science since the mid of $19^{\text {th }}$ century (1856).
} 
systematic thinking, clear, consistent methods, and seeking for the enlightenment of the truth. To indoctrinate people using the religious approach seems to be able to be succeed in many cases in Indonesia, including also to enhance the quality of human resource for the Indonesian people. However, the point to be concerned about is that the doctrines should be ensured to use the true religious approaches which are based on the true Islamic philosophical concept, "Kasbi or Khushuli" and "Ladunni or Hudhuri". Finally, an expected high-quality of human resource for Indonesia, which is "The Right Man in The Right Place", will then be achieved.

The role of philosophy to build good character and qualified human resources in Indonesia should be enhanced; one is to provide the knowledge of Philosophy Science for humans, starting from the stage of knowing, understanding, and going to the level of internalising and further practicing. The Science of Philosophy should be taught in proper ways by modifying the way of traditional teaching methods to useful teaching rules in higher education-an interactive learning process between educators and students. With education (formal and non-formal), mastering the theory, internalizing the knowledge, and harmonizing all of these with practice with their own philosophy of life, the balance of their life will be achieved.

Having done these proposed recommendations- "Conceptual Thinking on Enhancement of the Quality of Human Resource by the Philosophical Approach in Short- and Long-Term Phases", as well as "Modified Teaching Rules of Philosophical Science"-therefore, the human resources for Indonesia must have these abilities: firstly, to think critically, logically, comprehensively to the roots; secondly, to think conceptually, systematically, and argumentatively; and thirdly, to be responsible. These three main abilities are also based on exemplary values that are exemplified in a good life, useful and beneficial to their lives, including those beneficial and responsible to their environment, surroundings, and communities.

\section{References}

Asy'arie, M. (2001). Filsafat Islam Sunnah Nabi dalam Berpikir (Islamic Philosophy of the Prophet's Thinking). Yogyakarta, Central Java, Indonesia: Lembaga Studi Filsafat Islam (LESFI).

Darmodiharjo, D. \&. (1999). Pokok-Pokok Filsafat Hukum (Principles of Philosophy of Law) (Revisi ed.). Jakarta, DKI Jakarta, Indonesia: Gramedia Pustaka Utama.

Darmodiharjo, D. (2000). Bahan Kuliah Filsafat Hukum (Lecture Note on Philosophy of Law). Jakarta, DKI Jakarta, Indonesia: Post Graduate Studies, Master of Law, Universitas Tarumanagara.

Ghazali, A. R. (2002, November 4). Manusia, Kekerasan dan Fungsi Agama (Human, Violence and Religious Functions). Kompas, p. 6.

Manan, B. (7 September 2001). Peranan Hakim dalam Reformasi Hukum (The Role of Judges in Legal Form). Stadium Generale in New Academic Year 2001/2002. Jakarta: Post Graduate Studies, Master of Law, Universitas Tarumanagara.

Nurdin, B. (2012). Kedudukan dan Fungsi Hakim dalam Penegakan Hukum di Indonesia (The Position and Function of Judges for Law Enforcement in Indonesia). Bandung, West Java, Indonesia: Alumni.

Nurdin, B. (2014). Filsafat Hukum (Tokoh-tokoh Penting Filsafat: Sejarah dan Intisari Pemikiran) (Philosophy of Law: Famous Philosophers: History and Their Essential Thoughts). Jakarta, Indonesia: Pustaka Litera Antar Nusa.

Poespowardojo, S. (2013, October 10). Filsafat harus jadi Mata Kuliah wajib Pasca Sarjana. Retrieved from http://www.sesawi.net/2012/10/09/filsafat-harus-jadi-mata-kuliah-wajib-pascas

Schmandt, H. J. (2002). Filsafat Politik (Political Philosophy). (A. B. Bahehaqi, Trans.) Jakarta, DKI Jakarta, Indonesia: Pustaka Pelajar Offset. 